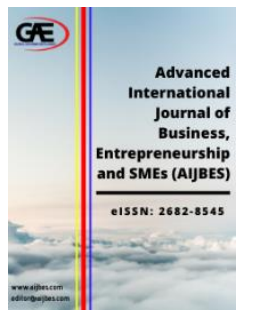

\author{
ADVANCED INTERNATIONAL JOURNAL OF \\ BUSINESS, ENTREPRENEURSHIP AND SMES \\ (AIJBES) \\ www.aijbes.com
}

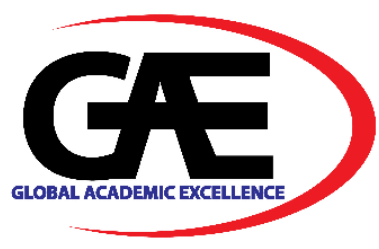

\title{
THE ACCULTURATION TO GLOBAL CONSUMER CULTURE TOWARDS PURCHASE DECISION OF SOUTH KOREAN SKINCARE AND COSMETIC PRODUCT
}

\author{
Alya Indira Putri ${ }^{1 *}$, \\ 1 School of Business and Management, Institut Teknologi Bandung, Indonesia \\ Email: alya_indira@sbm-itb@ac.id \\ * Corresponding Author
}

\section{Article Info: \\ Article history: \\ Received date: 10.06 .2021 \\ Revised date: 13.06 .2021 \\ Accepted date: 29.07.2021 \\ Published date: 01.09.2021 \\ To cite this document: \\ Putri, A. I. (2021). The Acculturation to Global Consumer Culture towards Purchase Decision of South Korean Skincare and Cosmetic Product. Advanced International Journal of Business, Entrepreneurship and SMEs, 3 (9), 102-122.}

DOI: $10.35631 /$ AIJBES.39008.

This work is licensed under CC BY 4.0 (c) (2)

\begin{abstract}
:
The development of the globalization era encourages the dissemination of information and beauty trends from South Korea in Indonesia. To be accepted by the Indonesian market, South Korean beauty companies need to consider the acculturation aspects, because it is one of the primary determinant factors of consumer purchase decisions in a foreign country product. The purpose of this study is to analyze the effect of acculturation on global consumer culture towards purchase decisions of South Korean skincare and cosmetic products, identify the factors that influence the consumers' purchase decision, and develop marketing recommendations for South Korean beauty companies. To validate the hypotheses from previous studies and answer the research questions, a quantitative approach by the online survey was conducted by 250 respondents of women in Indonesia from generations $\mathrm{x}, \mathrm{y}$, and $\mathrm{z}$ who have purchased South Korean skincare and cosmetic products by a minimum of past six months, and PLS-SEM was used to analyze the relationship between the variables. The findings indicate that acculturation influences customers' purchase decisions towards South Korean skincare and cosmetic products through several variables. It is found that cosmopolitanism has a significant influence on global consumption orientation and perceived value. Similarly, global mass exposure and self-identification with GCC have a significant impact on materialism. Materialism then has a significant impact on perceived value, which in turn has a significant influence on brand attitude. Brand attitudes then have a significant influence on purchase intention, which in turn has a significant influence on the purchase decision. The results suggested that South Korean beauty companies should maintain product quality, emphasize the products' benefit and function, and enhance the advertising competitive advantage. This study is expected to enhance marketers understanding of how
\end{abstract}


Volume 3 Issue 9 (September 2021) PP. 102-122

AGCC; Cosmetic; Purchase Decision; Skincare; South Korea

\section{Introduction}

The Korean Wave's success in Asia is constantly strengthened by accelerated industrialisation, which drives regional economic growth and rapid intra-regional trade growth (E. M. Kim \& Ryoo, 2007). The key factor introducing the Korean Wave globally is their music and film industry (Ravina, 2009). Therefore, this fuelled a surge in interest and circulation for South Korean products (Tjoe \& Kim, 2016).

The presence of South Korean celebrities inspired people to imitate their idol lifestyle that led to increase the South Korean beauty trends (Burhanuddin, 2016). Furthermore, this generates a big influence in South Korean brands' popularity growth. South Korea gained an impression of a country with attractive people and perceived as a leader in cosmetic innovation. Additionally, South Korea beauty trends are now often used as a benchmark for recent fashion trends.

Cleveland and Laroche (2007) explained that culture influences a range of consumption behaviour. Lee and Tse (1994), stated that acculturation as a transaction would begin with the integration of more than two self-regulating cultural systems caused by the collision of two cultures. This has already started because the South Korean culture and product have been quickly adopted by Indonesians, even though both countries have distinct cultures (Rahmiati \& Lita, 2012).

According to Worldbank.org, Indonesia is the fourth most populous country in the world to be a potential market for foreign products, making Indonesia the ideal target market for foreign products. Every year, the beauty outlook grows and becomes a regular expectation for all women who believe that it will lead to better future prospects (Rohmitriasih, 2018). Previous research shown that despite the slowing economy, Indonesian women continue to purchase beauty products. (Indonesia Investment, 2017).

Korean Wave has influenced acculturation which leads to beauty consumption due to the beauty ideals formed (K. J. Kim \& Han, 2018). Along with the consumer desire in beauty product usage that drastically increases, lead cosmetic industries produce even more beauty products in the world (Burhanuddin, 2016). However, South Korea's largest cosmetics company reported a net profit decline of 93.1 percent in the second quarter of 2020, compared to the same period last year (Ermaningtiastuti, 2020)

This decline in South Korean beauty product sales is influenced by consumer purchasing decisions, as there are currently a plethora of other beauty brand products available (Gautama, 2015). Furthermore, this has an effect on the market share because consumers migrate to other beauty brands that are more appealing to them. Therefore, it would be more difficult for South 
Volume 3 Issue 9 (September 2021) PP. 102-122 DOI 10.35631/AIJBES.39008

Korean skincare and cosmetics companies in Indonesia to get Indonesian consumers to select their products from a number of alternatives offered by other brands from the same industry.

Rather than any other aspect, culture is the primary determinant of consumer attitudes, behaviour and lifestyles, and thus of the needs that consumers fulfil by the purchase and use of products and services (Cleveland \& Laroche, 2007). If a business understands consumer behaviour and can relate to the culture, it will be easier to make business and marketing strategy decisions (Newman, 2016). AGCC acts as the research paradigm that is able to examine the complex relationship between local and global cultural effects on customer behaviour (Cleveland \& Laroche, 2007).

The purpose of this study attempts to study the influence of AGCC towards purchase decisions of South Korean skincare and cosmetic brands. By having a conclusion about this phenomenon, the South Korean beauty companies could make a better consideration in applying knowledge and conducting specific activities to appeal to the Indonesian market in the future.

\section{Literature Review}

\section{Korean Wave}

Korean Wave is a noteworthy form of South Korean popular culture that was presented through their countries' media alongside with the line of commercial nationalism. As the Korean wave has demonstrated, Korean regional cultures have thus become the global trend (Lee, 2011). The Korean wave has become one way of internationally introducing Korean culture (Ravina, 2009). Furthermore, the wave also consists mainly of two kinds of media: TV shows and pop music (K-Pop), but it also includes Korean features and other forms of music.

The Korean Wave has a major impact on awareness of product and cultural exchange among different countries (Rahmiati \& Lita, 2012). Korean Wave is a marketing and commercial phenomena that involves substantial attempts on the part of promoters, publicists, and corporate agents to offer Korean culture as a product (Tjoe \& Kim, 2016).

The spread of Korean pop culture began in 2002 in Indonesia (Putri et al., 2019). The phenomenon started in Indonesia when they changed their lifestyle following Korean stars (Rahmiati \& Lita, 2012). Despite the fact that the two nations' cultures are vastly different, Korean culture and goods have readily penetrated the Indonesian people (Mariani, 2008). The international expansion of the Korean wave craze increased demand for Korean products, boosting South Korea's exports and generating billions (Tan et al., 2020). In other words, through Korean wave, people recognize the Korean brand (Rahmiati \& Lita, 2012).

\section{Acculturation to Global Consumer Culture (AGCC)}

Cleveland (2006) simply states that acculturation to global consumer culture "considers how individuals acquire the knowledge, skills, and behaviors that are characteristic of a nascent and deterritorialized global consumer culture". Following a thorough examination of relevant literature, six suggested dimensions were shown. Cleveland (2006) defined AGCC as having many aspects, which are as follows: 
Volume 3 Issue 9 (September 2021) PP. 102-122 DOI 10.35631/AIJBES.39008

- Cosmopolitanism (COS): Cosmopolitan persons are most likely to engage with and be able to participate in other cultures. (Cleveland \& Laroche, 2007). The previous study has shown that consumer Cosmopolitanism (COS) is an identity-based predictor of increased access to positive Perceived Value (PV) of a global brand (Alden et al., 2013). Kelley (2010) stated that the consumer who have a higher Cosmopolitanism (COS) will have a more positive global Brand Attitude (BA) and Brand Attitude (BA). Thus, this leads to the the hypothesis as follows:

H1: There is a significant influence between Cosmopolitanism (COS) and Global Consumption Orientation (GCO) towards South Korean skincare and cosmetic brands.

H2: There is a significant influence between Cosmopolitanism (COS) and Brand Attitude (BA) towards South Korean skincare and cosmetic brands.

H3: There is a significant influence between Cosmopolitanism (COS) and Perceived Value (PV) towards South Korean skincare and cosmetic brands.

- Exposure to Marketing Activities of Multinational Corporations (EXM): Advertising and other forms of promotion are the means by which product information is transferred and transformed into a purchase decision. As a result, most marketers today are more aggressive in their efforts to reach beyond national borders (Cleveland \& Laroche, 2007).

- Global Mass Exposure (GMM): The global and foreign mass media can be composed of a variety of media, including television, the internet, and magazines (Cleveland \& Laroche, 2007).

- Openness to and Desire to Emulate Global Consumer Culture (OPE): Numerous researchers have demonstrated that individuals who admire the lifestyles of other countries (e.g., Alden et al., 1999; Appadurai, 1990; Batra et al., 2000) desire ownership of consumption symbols from those countries.

- Self-identification with global consumer culture (IDT): Reflects an individual's desire to dress, read, and interact with international brands in ways that reflect global consumer movement (Cleveland \& Laroche, 2007).

The result of previous study revealed that Acculturation to Global Consumer Culture (AGCC) associates positively with Materialism (MAT) (Cleveland et al., 2015). Therefore, this statement leads to the hypothesis as follows:

H4: There is a significant influence between the Acculturation to Global Consumer Culture (AGCC) and Materialism (MAT) toward South Korean skincare and cosmetic brands.

- H4a: There is a significant influence between Cosmopolitanism (COS) and Materialism (MAT) toward South Korean skincare and cosmetic brands.

- H4b: There is a significant influence between Exposure to Marketing Activities (EXM) and Materialism (MAT) toward South Korean skincare and cosmetic brands.

- H4c: There is a significant influence between Global Mass Exposure (GMM) and Materialism (MAT) toward South Korean skincare and cosmetic brands. 
Volume 3 Issue 9 (September 2021) PP. 102-122 DOI 10.35631/AIJBES.39008

- H4d: There is a significant influence between Openness and Desire to Emulate GCC (OPE) and Materialism (MAT) toward South Korean skincare and cosmetic brands.

- H4e: There is a significant influence between Self-identification with GCC (IDT) and Materialism (MAT) toward South Korean skincare and cosmetic brands.

\section{Global Consumption Orientation (GCO)}

The term of global consumption orientation refers to a set of attitudes toward globalized, localized, or hybridized alternatives across a range of consumption domains (Alden et al., 2006). The foundation of this construct is based on prior research indicating the emergence of a global consumer culture (Alden et al., 1999) that has motivate firms to pursue strategies of establishing of global brands (Steenkamp et al., 2002) and segmenting the consumer market according to the cross-national profiles (Hassan and Katsanis, 1994). The study conducted by Westjohn (2009) revealed that Global Consumption Orientation (GCO) has a positive effect on the global Brand Attitude (BA). Therefore, this statement leads to the hypothesis as follows:

H5: There is a significant influence between Global Consumption Orientation (GCO) and Brand Attitude (BA) towards South Korean skincare and cosmetic brands.

\section{Materialism (MAT)}

Materialism is described as a value that influences people's choices and behavior in a variety of contexts, including but not limited to consumption zones (Richins \& Dawson, 1992). Additionally, materialism may have an effect on the type and quantity of goods purchased, as well as the distribution of a variety of resources. The consumers who are more materialistic will have a higher perceived value (Kelley, 2010). Therefore, this statement leads to the hypothesis as follows:

H6: There is a significant influence between Materialism (MAT) and Perceived Value (PV) towards South Korean skincare and cosmetic brands.

\section{Perceived Value (PV)}

Perceived value is determined through an aggregate analysis of the costs and benefits associated with a particular market proposition in a particular consumer context. It refers to the net benefit that customers obtain as a result of their consumer behavior (Zeithaml, 1988). Positive perceived value has a corresponding influence on brand attitudes. As a result, perceived value serves as a useful indicator of brand attitudes. Therefore, this statement leads to the hypothesis as follows:

H7: There is a significant influence between Perceived Value (PV) and Brand Attitude (BA) towards South Korean skincare and cosmetic brands.

\section{Brand Attitude (BA)}

Brand attitude are essential because they often serve as the foundation for consumer behavior (Keller, 2013) as they refer to the consumer's willingness to respond constantly and exhibit a desirable or undesirable reaction toward a particular brand (Yim et al., 2014). A positive brand attitudes consequently influence purchase intention (Riefler, 2012). The brand attitudes provides a useful purchase intention indicator. The hypothesis proposed is as follows: 
Volume 3 Issue 9 (September 2021) PP. 102-122

DOI 10.35631/AIJBES.39008

H8: There is a significant influence between Brand Attitude (BA) and Purchase Intention (PI) towards South Korean skincare and cosmetic brands

\section{Purchase Intention (PI)}

Customers' intentions are one of the most frequently used approaches by marketers to gain a better understanding of their actual behavior (Schiffman \& Kanuk, 2010). Intentions serve as a representation of the motivating factors that influence behavior and they may indicate the level of commitment they wish to develop and execute their behavior. (Ajzen, 1991). Purchase intentions should be predictive of future actions because they enable consumers to factor in the factors that are most important to them when making a purchase (Morwitz, 2014). When there is a strong desire to engage in a particular behavior, there are higher likelihoods that the respective behavior will be performed (Ajzen, 1991). Therefore, this statement leads to the hypothesis as follows:

H9: There is a significant influence between Purchase Intention (PI) and Purchase Decision (PD) towards South Korean skincare and cosmetic brands.

\section{Purchase Decision (PD)}

Purchase decision is the process of formulating an alternative action to indicate the selection of one specific alternative to make the purchase (Kotler \& Keller, 2009). Consumer purchasing decisions demonstrated the likelihood of an individual's willingness to purchase a particular product (Dodds et al., 1991). The success in selling goods and services occurred when the marketer could interpret their customer behavior in accordance with their consumer purchase decision process very well (Qazzafi, 2019).

This study shows that there are eleven factors that customers should consider before purchasing South Korean skincare and cosmetic brand products on the discussion. This research's findings can benefit readers and provide South Korean beauty brands with insights to help marketing strategies development.

The researcher uses framework (Figure 1) in this study which comprises variables that correlated with acculturation effect on purchase decision of Korean skincare and cosmetic brand products. After evaluating the preceding associated study, the framework and variables are generated and combined from Cleveland et al., (2015); Alden et al., (2013); Kelley (2010); Naseem et al., (2015) and Peña-García et al., (2020). The proposed conceptual framework for this research is as follows: 
AGCC

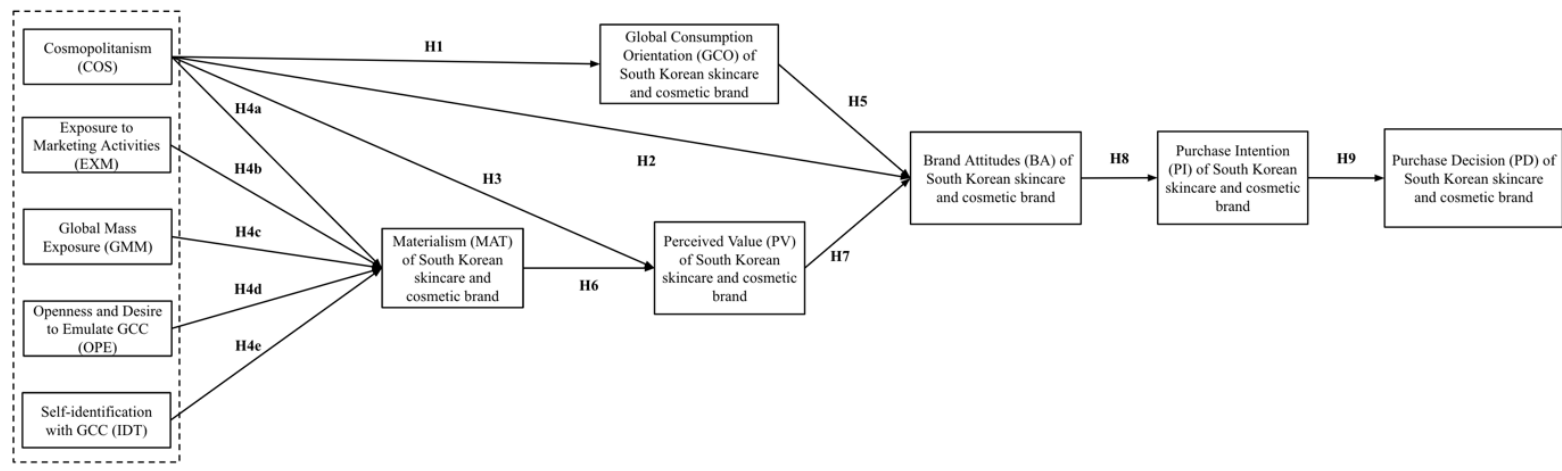

Source: Author's Interpretation

Figure 1. Conceptual Framework

According from the figure, the key factors which come from AGCC dimensions that are: cosmopolitanism, exposure to marketing activities, global mass exposure, openness and desire to emulate global consumer culture, self-identification with global consumer culture. This culture factors can influence consumer attitudes, behaviors and lifestyles and thus of the needs that consumers fulfil by the purchase and use of products and services (Cleveland \& Laroche, 2007). Purchase decisions are linked to consumer buying behavior, which is described as the process by which customers make purchases, use, and set purchased items and services, as well as the variables that affect purchase decisions and buyer behavior (Lamb et al., 2011).

The paper combines the cultural and socio-psychological perspectives of South Korean skincare and cosmetic product purchase behavior using conceptual framework the direct influences of AGCC dimensions on materialism, then the materialism has a direct influence on perceived value. There are also direct links between cosmopolitanism and global consumption orientation, perceived value, and materialism. Global consumption orientation, cosmopolitanism, and perceived value all have a direct impact on brand attitudes. Following that, brand attitudes have a direct impact on purchase intention. The purchase intention has a direct influence on the purchase decision. 
Source: Author's Interpretation

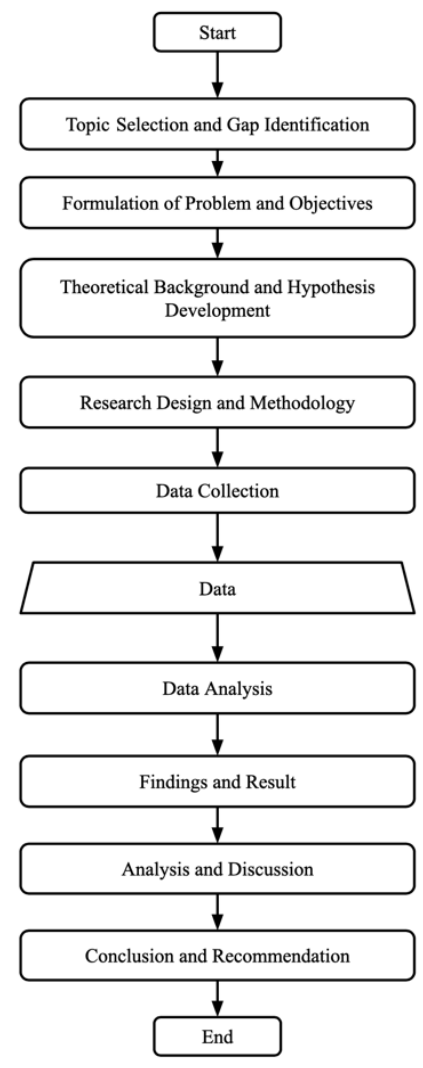

Figure 2. Research Design Flowchart

\section{Step 1: Topic Selection and Gap Identification}

The researcher chooses the research topic and finds whether the topic has been studied before or not and tries to find the gap between the researcher's topic and previous studies. After we identified the gap, the researcher started to create research objectives and questions of the study.

\section{Step 2: Formulation of Problem and Objectives}

After the topic is already feasible and chosen, next this research acquires conceptual ideas from some literature to sharpen the deep conceptual understanding of the researcher's topic and determine why the topic is important to be discussed to construct a research background and problem and formulate research questions and objectives. By completing this step, the researcher can begin searching for theories that will assist him or her in resolving the problem and achieving the study's objective.

\section{Step 3: Theoretical Background and Hypothesis Development}

This research takes this step to gain a better understanding of the subject and to familiarize itself with the theoretical underpinnings. This section is comprised of papers, articles, and other research conducted by other researchers prior to examining the effect of acculturation on purchase decisions for South Korean skincare and cosmetic brand products. In general, this 
Volume 3 Issue 9 (September 2021) PP. 102-122

DOI 10.35631/AIJBES.39008

literature review necessitates a more in-depth examination of variables, as well as the purpose and methodology of the study. Next, the researcher could propose the research design and conceptual framework by analyses and modifies a previously published journals and book reviews on related subjects.

\section{Step 4: Research Design and Methodology}

The research design incorporates a data collection system that entails compiling a sample of consumers who have purchased South Korean skincare and cosmetic brand products within the previous six months. The researcher will collect data for this study through an online questionnaire. Additionally, the author determines which analysis tools will be used to clean and analyze the data during this step. Following that, this research used Smart PLS to analyze the data. After chosen the right research design and methodology, the researcher started to collect the data and analyze the recorded data.

\section{Step 5: Data Collection and Data Analysis}

The data were quantitatively gathered. The quantitative approach is based on a survey, which is administered through an online questionnaire hosted on Google Forms. The sample size refers to the total number of respondents to the survey. The researcher uses Malhotra's rule to determine the sample size. According to Malhotra (2007), the recommended minimum sample size for marketing studies is 200 . The sample size for this study was 250 , in accordance with Malhotra's criteria.

The population for this study is the key market segment for beauty products, specifically women who have purchased South Korean skincare and cosmetic brands in the last six months. The female segment was chosen because, according to Allied Market Research (2019), there is an increase in the number of Indonesian women who are aware of their appearance, personal well-being, and grooming, and the female segment dominated the Indonesia skin care products market, accounting for more than half of market share. Additionally, the data indicates that generation $\mathrm{x}, \mathrm{y}$, and $\mathrm{z}$ are the primary target markets for beauty products in Indonesia and those are between the ages of 16 and 60 (Yeomans, 2018).

Participants in the survey must meet all requirements prior to completing the online survey. Participants can provide insight into this research by providing information about their perception and experience of how acculturation influences their purchase decisions.

The researcher employed a technique known as non-probability sampling in this study. Nonprobability sampling is a sampling approach in which, rather of selecting samples randomly, the researcher chooses samples based on the researcher's subjective judgment (Fleetwood, 2020). This method is used because the absence of a complete population list and is an effective way to generate ideas and solicit feedback (Howard, 2019). Non-probability sampling is divided into four categories. However, in this study the author used judgmental or purposive sampling.

Judgmental or purposive sampling is a technique in which the sample participants are selected only on the basis of the expertise and judgement of the researcher. This sampling method is chosen because it enables researchers to make generalizations about their sample and allows them to gain as much insight as possible into whatever key point is being observed or examined 
Volume 3 Issue 9 (September 2021) PP. 102-122

DOI 10.35631/AIJBES.39008

(Regoli, 2019). Due to the background of this research to know the effect of acculturation to global consumer culture influences the customers purchase decision of South Korean skincare and cosmetics brand products. The minimum number sample size that is needed for marketing study is 200 samples (Malhotra, 2012). The selected sample should meet the requirement of having bought the South Korean skincare and cosmetic brand products during minimum of the past six months, so that the respondent is already familiar with the use of products.

The researcher collects and analyzes data using research design and planning tools. The researcher cleans data that does not meet the criteria and then analyzes it using the Smart PLS software. Following that, the researcher eliminated irrelevant indicators and performed various types of analysis in order to develop an excellent construct model. After developing an appropriate model, the researcher can obtain data analysis findings and results.

\section{Step 6: Findings and Result}

The researcher presents all findings and outcomes from the data analysis performed by the Smart PLS program during this stage. This data will be further examined during the discussion and analysis stages with the goal of generating and presenting descriptive data on the effect of acculturation to global consumer culture on the purchasing decision of South Korean skincare and cosmetic brand products. Following the presentation of the findings and results, the researcher may conduct deeper analysis and create discussion in order to give rise to an argument.

\section{Step 7: Analysis and Discussion}

The author will synthesize the findings, accept or reject hypotheses, and amplify hypotheses through connections to past research and thorough analysis to explain empirical findings using previously defined variables and their impact on the South Korean skincare and cosmetic product purchase decision. After the arguments delivered through discussion, the researcher could make a conclusion and formulate recommendation.

\section{Step 8: Conclusion and Recommendation}

The final step of this research is the conclusion and recommendations. The data that has been generated from the interview and survey were analyzed and discussed to generate the effect of acculturation to global consumer culture towards the purchase decision of South Korean skincare and cosmetic brand products. This research may also address recommendations and considerations that will be helpful for future research on this topic.

\section{Results and Findings}

In order to conduct the analysis and develop a valid and reliable model, several critical steps must be completed. These steps include establishing indicator reliability, internal consistency reliability, convergent validity, and discriminant validity. Figure 2 illustrates the calculation result. 
Source: Author's Interpretation

Figure 2. PLS-SEM Result

This proposed model is composed of eleven variables connected through the use of twelve paths. The following diagram depicts the calculations for the reflective measuring model. The confirmed model of this study consists of 11 latent variables and 47 indicators.

\section{Measurement Model Results}

\section{Indicator Reliability Test}

The outer loadings denote the indicator's absolute contribution to defining its latent variable (Garson, 2016). Correlations between a construct and each of its manifest variables, expressed as absolute standardized outer loadings, should be greater than 0.7 (Henseler et al., 2009). The outcome of the outer loadings indicates that some indicators have been identified as unreliable. The indicators are COS4, COS7, EXM1, EXM5, EXM6, EXM7, GMM6, OPE4, IDT7, IDT8, PV2.

Table 1: Indicator Reliability Test

\begin{tabular}{cccc}
\hline Variables & Label & Outer Loadings & Reliability \\
\hline Cosmopolitanism (COS) & COS1 & 0,831 & Reliable \\
\cline { 2 - 4 } & COS2 & 0,827 & Reliable \\
\cline { 2 - 4 } & COS3 & 0,852 & Reliable \\
\hline COS4 & 0,485 & Not Reliable \\
\hline & COS5 & 0,771 & Reliable \\
\hline COS6 & 0,814 & Reliable \\
\hline COS7 & 0,270 & Not Reliable \\
\hline & EXM1 & 0,592 & Not Reliable \\
\hline
\end{tabular}


Volume 3 Issue 9 (September 2021) PP. 102-122

DOI 10.35631/AIJBES.39008

\begin{tabular}{|c|c|c|c|}
\hline \multirow{7}{*}{$\begin{array}{l}\text { Exposure to Marketing } \\
\text { Activities of Multinational } \\
\text { Corporations (EXM) }\end{array}$} & EXM2 & 0,760 & Reliable \\
\hline & EXM3 & 0,706 & Reliable \\
\hline & EXM4 & 0,760 & Reliable \\
\hline & EXM5 & 0,641 & Not Reliable \\
\hline & EXM6 & 0,655 & Not Reliable \\
\hline & EXM7 & 0,566 & Not Reliable \\
\hline & EXM8 & 0,771 & Reliable \\
\hline \multirow{8}{*}{$\begin{array}{l}\text { Exposure to Global and } \\
\text { Foreign Mass Media } \\
(\mathrm{GMM})\end{array}$} & GMM1 & 0,790 & Reliable \\
\hline & GMM2 & 0,709 & Reliable \\
\hline & GMM3 & 0,868 & Reliable \\
\hline & GMM4 & 0,715 & Reliable \\
\hline & GMM5 & 0,757 & Reliable \\
\hline & GMM6 & 0,678 & Not Reliable \\
\hline & GMM7 & 0,762 & Reliable \\
\hline & GMM8 & 0,710 & Reliable \\
\hline \multirow{4}{*}{$\begin{array}{l}\text { Openness to and Desire to } \\
\text { Emulate Global Consumer } \\
\text { Culture (OPE) }\end{array}$} & OPE1 & 0,745 & Reliable \\
\hline & OPE2 & 0,885 & Reliable \\
\hline & OPE3 & 0,868 & Reliable \\
\hline & OPE4 & 0,694 & Not Reliable \\
\hline \multirow{8}{*}{$\begin{array}{l}\text { Self-identification with } \\
\text { global consumer culture } \\
\text { (IDT) }\end{array}$} & IDT1 & 0,744 & Reliable \\
\hline & IDT2 & 0,758 & Reliable \\
\hline & IDT3 & 0,783 & Reliable \\
\hline & IDT4 & 0,838 & Reliable \\
\hline & IDT5 & 0,743 & Reliable \\
\hline & IDT6 & 0,717 & Reliable \\
\hline & IDT7 & 0,696 & Not Reliable \\
\hline & IDT8 & 0,597 & Not Reliable \\
\hline \multirow{3}{*}{$\begin{array}{l}\text { Global Consumption } \\
\text { Orientation }(\mathrm{GCO})\end{array}$} & GCO1 & 0,706 & Reliable \\
\hline & GCO2 & 0,809 & Reliable \\
\hline & GCO3 & 0,828 & Reliable \\
\hline \multirow[t]{4}{*}{ Materialism (MAT) } & MAT1 & 0,777 & Reliable \\
\hline & MAT2 & 0,769 & Reliable \\
\hline & MAT3 & 0,814 & Reliable \\
\hline & MAT4 & 0,772 & Reliable \\
\hline \multirow[t]{6}{*}{ Perceived Value (PV) } & PV1 & 0,796 & Reliable \\
\hline & PV2 & 0,686 & Not Reliable \\
\hline & PV3 & 0,707 & Reliable \\
\hline & PV4 & 0,864 & Reliable \\
\hline & PV5 & 0,843 & Reliable \\
\hline & PV6 & 0,837 & Reliable \\
\hline \multirow[t]{5}{*}{ Brand Attitude (BA) } & BA1 & 0,852 & Reliable \\
\hline & BA2 & 0,882 & Reliable \\
\hline & BA3 & 0,815 & Reliable \\
\hline & BA4 & 0,865 & Reliable \\
\hline & BA5 & 0,860 & Reliable \\
\hline
\end{tabular}


Volume 3 Issue 9 (September 2021) PP. 102-122

DOI 10.35631/AIJBES.39008

\begin{tabular}{llll}
\hline Purchase Intention (PI) & PI1 & 0,911 & Reliable \\
\cline { 2 - 4 } & PI2 & 0,876 & Reliable \\
\cline { 2 - 4 } & PI3 & 0,924 & Reliable \\
\hline Purchase Decision (PD) & PD1 & 0,904 & Reliable \\
\cline { 2 - 4 } & PD2 & 0,868 & Reliable \\
\cline { 2 - 4 } & PD3 & 0,869 & Reliable \\
\hline
\end{tabular}

The unreliable indicator is removed by the researcher and rerun the calculation. The result is presented on Table 2 as follows.

Table 2: Indicator Reliability Test (Re-run)

\begin{tabular}{|c|c|c|c|}
\hline Variables & Label & Outer Loadings & Reliability \\
\hline \multirow[t]{5}{*}{ Cosmopolitanism (COS) } & COS1 & 0,856 & Reliable \\
\hline & COS2 & 0,861 & Reliable \\
\hline & COS3 & 0,867 & Reliable \\
\hline & COS5 & 0,786 & Reliable \\
\hline & COS6 & 0,839 & Reliable \\
\hline \multirow{4}{*}{$\begin{array}{l}\text { Exposure to Marketing } \\
\text { Activities of Multinational } \\
\text { Corporations (EXM) }\end{array}$} & EXM2 & 0,774 & Reliable \\
\hline & EXM3 & 0,720 & Reliable \\
\hline & EXM4 & 0,854 & Reliable \\
\hline & EXM8 & 0,812 & Reliable \\
\hline \multirow{7}{*}{$\begin{array}{l}\text { Exposure to Global and } \\
\text { Foreign Mass Media (GMM) }\end{array}$} & GMM1 & 0,818 & Reliable \\
\hline & GMM2 & 0,736 & Reliable \\
\hline & GMM3 & 0,884 & Reliable \\
\hline & GMM4 & 0,712 & Reliable \\
\hline & GMM5 & 0,703 & Reliable \\
\hline & GMM7 & 0,757 & Reliable \\
\hline & GMM8 & 0,734 & Reliable \\
\hline \multirow{3}{*}{$\begin{array}{l}\text { Openness to and Desire to } \\
\text { Emulate Global Consumer } \\
\text { Culture (OPE) }\end{array}$} & OPE1 & 0,813 & Reliable \\
\hline & OPE2 & 0,930 & Reliable \\
\hline & OPE3 & 0,913 & Reliable \\
\hline \multirow{6}{*}{$\begin{array}{l}\text { Self-identification with } \\
\text { global consumer culture } \\
\text { (IDT) }\end{array}$} & IDT1 & 0,818 & Reliable \\
\hline & IDT2 & 0,817 & Reliable \\
\hline & IDT3 & 0,840 & Reliable \\
\hline & IDT4 & 0,868 & Reliable \\
\hline & IDT5 & 0,741 & Reliable \\
\hline & IDT6 & 0,818 & Reliable \\
\hline \multirow{3}{*}{$\begin{array}{l}\text { Global Consumption } \\
\text { Orientation }(\mathrm{GCO})\end{array}$} & GCO1 & 0,704 & Reliable \\
\hline & GCO2 & 0,812 & Reliable \\
\hline & GCO3 & 0,825 & Reliable \\
\hline \multirow[t]{4}{*}{ Materialism (MAT) } & MAT1 & 0,786 & Reliable \\
\hline & MAT2 & 0,772 & Reliable \\
\hline & MAT3 & 0,805 & Reliable \\
\hline & MAT4 & 0,763 & Reliable \\
\hline Perceived Value (PV) & PV1 & 0,796 & Reliable \\
\hline
\end{tabular}


Volume 3 Issue 9 (September 2021) PP. 102-122 DOI 10.35631/AIJBES.39008

\begin{tabular}{llll}
\hline & PV3 & 0,883 & Reliable \\
\cline { 2 - 4 } & PV4 & 0,873 & Reliable \\
\cline { 2 - 4 } & PV5 & 0,874 & Reliable \\
\cline { 2 - 4 } Brand Attitude (BA) & PV6 & 0,796 & Reliable \\
\cline { 2 - 4 } & BA1 & 0,852 & Reliable \\
\cline { 2 - 4 } & BA2 & 0,883 & Reliable \\
\cline { 2 - 4 } & BA3 & 0,815 & Reliable \\
\cline { 2 - 4 } & BA4 & 0,864 & Reliable \\
\hline Purchase Intention (PI) & PI1 & 0,859 & Reliable \\
\cline { 2 - 4 } & PI2 & 0,911 & Reliable \\
\cline { 2 - 4 } & PI3 & 0,876 & Reliable \\
\hline Purchase Decision (PD) & PD1 & 0,904 & Reliable \\
\cline { 2 - 4 } & PD2 & 0,868 & Reliable \\
\cline { 2 - 4 } & PD3 & 0,869 & Reliable \\
\hline
\end{tabular}

According to the results in Table 2, all variables meet the minimum acceptable score. This indicates that all variables are reliable and can be analyzed further in the next step.

\section{Composite Reliability}

Table 3: Composite Reliability

\begin{tabular}{lcc}
\hline \multicolumn{1}{c}{ Variables } & $\begin{array}{c}\text { Composite } \\
\text { Reliability }\end{array}$ & Reliability \\
\hline Cosmopolitanism (COS) & 0,931 & Reliable \\
\hline $\begin{array}{l}\text { Exposure to Marketing Activities of } \\
\text { Multinational Corporations (EXM) }\end{array}$ & 0,924 & Reliable \\
\hline $\begin{array}{l}\text { Exposure to Global and Foreign } \\
\text { Mass Media (GMM) }\end{array}$ & 0,870 & Reliable \\
\hline $\begin{array}{l}\text { Openness to and Desire to Emulate } \\
\text { Global Consumer Culture (OPE) }\end{array}$ & 0,825 & Reliable \\
\hline $\begin{array}{l}\text { Self-identification with global } \\
\text { consumer culture (IDT) }\end{array}$ & 0,908 & Reliable \\
\hline $\begin{array}{l}\text { Global Consumption Orientation } \\
\text { (GCO) }\end{array}$ & 0,863 & Reliable \\
\hline Materialism (MAT) & 0,917 & Reliable \\
\hline Perceived Value (PV) & 0,909 & Reliable \\
\hline Brand Attitude (BA) & 0,912 & Reliable \\
\hline Purchase Intention (PI) & 0,931 & Reliable \\
\hline Purchase Decision (PD) & 0,910 & Reliable \\
\hline
\end{tabular}

Based on Table 3, the composite reliability values of all variables exceed the preferred score which is 0.7 . Therefore, all variables can be inferred as reliable. 


\section{Average Variance Extracted (AVE)}

Table 4: Average Variance Extracted (AVE)

\begin{tabular}{lcc}
\hline Variables & $\begin{array}{c}\text { Average Variance } \\
\text { Extracted (AVE) }\end{array}$ & Validity \\
\hline Cosmopolitanism (COS) & 0,731 & Valid \\
\hline $\begin{array}{l}\text { Exposure to Marketing Activities of } \\
\text { Multinational Corporations (EXM) }\end{array}$ & 0,710 & Valid \\
\hline $\begin{array}{l}\text { Exposure to Global and Foreign Mass } \\
\text { Media (GMM) }\end{array}$ & 0,626 & Valid \\
\hline $\begin{array}{l}\text { Openness to and Desire to Emulate } \\
\text { Global Consumer Culture (OPE) }\end{array}$ & 0,612 & Valid \\
$\begin{array}{l}\text { Self-identification with global consumer } \\
\text { culture (IDT) }\end{array}$ & 0,586 & Valid \\
\hline Global Consumption Orientation (GCO) & 0,612 & Valid \\
\hline Materialism (MAT) & 0,786 & Valid \\
\hline Perceived Value (PV) & 0,669 & Valid \\
\hline Brand Attitude (BA) & 0,775 & Valid \\
\hline Purchase Intention (PI) & 0,818 & Valid \\
\hline Purchase Decision (PD) & 0,669 & Valid \\
\hline
\end{tabular}

All of the variable's AVE values exceed 0.5, according to the AVE calculation result in Table 4.6 above. It means that all variables have been identified as valid.

\section{Discriminant Validity}

The square root values of the AVE are greater than the correlation values for all latent variables except the Perceived Value (PV). As a result, the cross loadings between each indicator must be examined, and the indicator with the lowest cross loading score must be removed. PV3 has the lowest cross loading score, so it is removed and researcher rerun the calculation.

Table 5: Discriminant Validity (Re-run)

\begin{tabular}{lccccccccccc}
\hline & BA & COS & EXM & GCO & GMM & MAT & OPE & PV & PD & PI & IDT \\
\hline BA & $\mathbf{0 , 8 5 5}$ & & & & & & & & & & \\
\hline COS & 0,361 & $\mathbf{0 , 8 4 3}$ & & & & & & & & & \\
\hline EXM & 0,264 & 0,269 & $\mathbf{0 , 7 9 1}$ & & & & & & & & \\
\hline GCO & 0,324 & 0,546 & 0,290 & $\mathbf{0 , 7 8 2}$ & & & & & & & \\
\hline GMM & 0,375 & 0,673 & 0,187 & 0,641 & $\mathbf{0 , 7 6 6}$ & & & & & & \\
\hline MAT & 0,394 & 0,332 & 0,283 & 0,556 & 0,384 & $\mathbf{0 , 7 8 2}$ & & & & & \\
\hline OPE & 0,236 & 0,314 & 0,314 & 0,468 & 0,331 & 0,370 & $\mathbf{0 , 8 8 7}$ & & & & \\
\hline PV & 0,845 & 0,362 & 0,277 & 0,351 & 0,355 & 0,399 & 0,262 & $\mathbf{0 , 8 5 7}$ & & & \\
\hline PD & 0,779 & 0,419 & 0,209 & 0,342 & 0,395 & 0,369 & 0,246 & 0,749 & $\mathbf{0 , 8 8 0}$ & & \\
\hline PI & 0,761 & 0,369 & 0,233 & 0,367 & 0,419 & 0,439 & 0,255 & 0,735 & 0,814 & $\mathbf{0 , 9 0 4}$ & \\
\hline IDT & 0,426 & 0,535 & 0,420 & 0,645 & 0,531 & 0,517 & 0,479 & 0,439 & 0,484 & 0,469 & $\mathbf{0 , 8 1 8}$ \\
\hline
\end{tabular}


Volume 3 Issue 9 (September 2021) PP. 102-122 DOI 10.35631/AIJBES.39008

The square root values of all variables AVE are greater than the correlation values in both the row and column of latent variables, as shown in Table 5. As a result, all variables pass the discriminant validity test.

\section{Collinearity Test}

The collinearity test is performed to avoid collinearity issues, as evidenced by the Variance Inflation Factor result (VIF) (Wong, 2013). VIF with a value of 5 or less is preferred. All of the indicators meet the preferred value because their values are less than 5 . This means that there are no issues with multicollinearity.

\section{Structural Path Significance}

Table 6: Discriminant Validity (Re-run)

$\begin{array}{cccccc}\underset{\text { Original }}{\text { Sample }} & \begin{array}{c}\text { Sample } \\ \text { Mean }\end{array} & \text { STDEV } & \begin{array}{c}\text { T- } \\ \text { Statistics }\end{array} & \mathbf{R}^{2} & \mathbf{Q}^{2} \\ (\mathrm{O}) & (\mathrm{M}) & & & & \end{array}$

\begin{tabular}{|c|c|c|c|c|c|c|}
\hline BA -> PI & 0,761 & 0,760 & 0,031 & 24,925 & 0,577 & 0,464 \\
\hline COS $->$ BA & 0,064 & 0,062 & 0,044 & 1,450 & \multirow[t]{3}{*}{0,713} & \multirow[t]{3}{*}{0,517} \\
\hline PV -> BA & 0,821 & 0,820 & 0,026 & 31,671 & & \\
\hline GCO $->$ BA & 0,001 & 0,004 & 0,040 & 0,026 & & \\
\hline COS -> GCO & 0,546 & 0,548 & 0,044 & 12,403 & 0,296 & 0,167 \\
\hline COS -> PV & 0,258 & 0,262 & 0,068 & 3,808 & \multirow[t]{2}{*}{0,212} & \multirow[t]{2}{*}{0,154} \\
\hline MAT-> PV & 0,314 & 0,316 & 0,060 & 5,245 & & \\
\hline COS -> MAT & $-0,021$ & $-0,028$ & 0,076 & 0,279 & \multirow[t]{5}{*}{0,290} & \multirow[t]{5}{*}{0,149} \\
\hline EXM -> MAT & 0,070 & 0,077 & 0,056 & 1,263 & & \\
\hline GMM -> MAT & 0,153 & 0,162 & 0,071 & 2,149 & & \\
\hline OPE -> MAT & 0,135 & 0,140 & 0,071 & 1,908 & & \\
\hline IDT -> MAT & 0,353 & 0,344 & 0,089 & 4,030 & & \\
\hline PI -> PD & 0,814 & 0,816 & 0,022 & 39,575 & 0,661 & 0,506 \\
\hline
\end{tabular}

From Table 6 it can be concluded that there are four path coefficients that are not significant since the T-statistics value is below 1.96. The "Cosmopolitanism $\rightarrow$ Brand Attitude" Tstatistics value is 1.450. The "Global Consumption Orientation -> Brand Attitude" T-statistics value is 0.026 . The "Cosmopolitanism $\rightarrow$ Materialism" T-statistics value is 0.279 . The "Exposure to Marketing Activities -> Materialism" T-statistics value is 1.263. Besides, all others path coefficients in this inner model are significant.

The Goodness-of-Fit (GoF)

Table 7: The Goodness-of-Fit (GoF)

\begin{tabular}{lcc}
\hline & $\mathbf{Q}^{\mathbf{2}}$ & $\mathbf{R}^{\mathbf{2}}$ \\
\hline Brand Attitude & 0,517 & 0,713 \\
\hline Global Consumption Orientation & 0,167 & 0,296 \\
\hline Materialism & 0,149 & 0,290 \\
\hline Perceived Value & 0,154 & 0,212 \\
\hline
\end{tabular}


Volume 3 Issue 9 (September 2021) PP. 102-122

DOI 10.35631/AIJBES.39008

\begin{tabular}{lll}
\hline Purchase Decision & 0,506 & 0,661 \\
\hline Purchase Intention & 0,464 & 0,577 \\
\hline Average & 0,326 & 0,458 \\
\hline GoF & & $\mathbf{0 , 2 2 1}$ \\
\end{tabular}

The GoF values range from 0 to 1 , with 0.10 (small), 0.25 (medium), and 0.36 (large) indicating the global validation of the PLS model (Hussain et al., 2018). This research model received a GoF value of 0.221 , indicating that it can explain the empirical data.

\section{Hypothesis Testing}

This section will demonstrate to use of the PLS calculation to describe the outcome of hypothesis testing based on the coefficient and significance of the inner model path from the tvalue. Table 8 displays the findings of the hypothesis testing.

Table 8: Hypothesis Testing

\begin{tabular}{|c|c|c|c|c|}
\hline Hypothesis & Structural Path & T-Value & P Value & Result \\
\hline H1 & $\begin{array}{l}\text { Cosmopolitanism -> } \\
\text { Global Consumption } \\
\text { Orientation }\end{array}$ & 12,403 & 0,000 & Accepted \\
\hline H2 & $\begin{array}{l}\text { Cosmopolitanism -> Brand } \\
\text { Attitude }\end{array}$ & 1,450 & 0,148 & Rejected \\
\hline H3 & $\begin{array}{l}\text { Cosmopolitanism -> } \\
\text { Perceived Value }\end{array}$ & 3,808 & 0,000 & Accepted \\
\hline H4a & $\begin{array}{l}\text { Cosmopolitanism -> } \\
\text { Materialism }\end{array}$ & 0,279 & 0,780 & Rejected \\
\hline H4b & $\begin{array}{l}\text { Exposure to Marketing } \\
\text { Activities }->\text { Materialism }\end{array}$ & 1,263 & 0,207 & Rejected \\
\hline H4c & $\begin{array}{l}\text { Global Mass Exposure -> } \\
\text { Materialism }\end{array}$ & 2,149 & 0,032 & Accepted \\
\hline H4d & $\begin{array}{l}\text { Openness and Desire to } \\
\text { Emulate GCC -> } \\
\text { Materialism }\end{array}$ & 1,908 & 0,057 & Rejected \\
\hline H4e & $\begin{array}{l}\text { Self-identification with } \\
\text { GCC -> Materialism }\end{array}$ & 4,030 & 0,000 & Accepted \\
\hline H5 & $\begin{array}{l}\text { Global Consumption } \\
\text { Orientation -> Brand } \\
\text { Attitude }\end{array}$ & 0,026 & 0,979 & Rejected \\
\hline H6 & $\begin{array}{l}\text { Materialism -> Perceived } \\
\text { Value }\end{array}$ & 5,245 & 0,000 & Accepted \\
\hline H7 & $\begin{array}{l}\text { Perceived Value -> Brand } \\
\text { Attitude }\end{array}$ & 31,671 & 0,000 & Accepted \\
\hline H8 & $\begin{array}{l}\text { Brand Attitude -> } \\
\text { Purchase Intention }\end{array}$ & 24,925 & 0,000 & Accepted \\
\hline H9 & $\begin{array}{l}\text { Purchase Intention -> } \\
\text { Purchase Decision }\end{array}$ & 39,575 & 0,000 & Accepted \\
\hline
\end{tabular}




\section{Discussion}

After evaluating the questionnaire result, it is found that acculturation to global consumer culture affect customers' purchase decision toward South Korean skincare and cosmetic products through a number of variables. According to the result of PLS-SEM analysis, customers' purchase decision toward purchase South Korean skincare and cosmetic products are influenced by cosmopolitanism, exposure to marketing activities, global mass exposure, openness and desire to emulate global consumer culture, self-identification with global consumer culture through global consumption orientation, perceived value, materialism, brand attitude and purchase intention. These findings are also consistent with the results of previous study. This study confirmed that cosmopolitanism has a significant influence on global consumption orientation and perceived value, implying that the higher the level of cosmopolitanism, the higher the level of global consumption orientation and perceived value. Similarly, global mass exposure and self-identification with the GCC have a significant impact on materialism. Materialism then has a significant impact on perceived value, which in turn has a significant impact on brand attitude. Brand attitudes then have a significant influence on purchase intention, which in turn has a significant influence on purchase decision. These represent the effects of acculturation to global consumer culture on South Korean skincare and cosmetic product purchases.

The growing acceptance and penetration of South Korean culture in Indonesia is attributed to the growth of the South Korean skincare and cosmetic market in the country. All the factors included in this study influence a customer's decision to purchase a South Korean beauty product, and the South Korean beauty industry could consider these factors when developing marketing initiatives for the Indonesia market. Following are some recommendations for South Korean beauty brands:

1. The South Korean skincare and cosmetics brand could hire an influencer to create a review video for their product, as data indicates that those who influence them are more likely to purchase South Korean skincare and cosmetics. Additionally, product reviews are a critical factor to consider when purchasing South Korean skincare and cosmetic products.

2. The South Korean skincare and cosmetics brand could use a friend's referral code strategy to effectively promote their product in Indonesia, as friends and family also play a significant role in influencing the purchase of beauty products.

3. The formulation of the products must also be maintained and innovated upon, as South Korean skincare and cosmetic products have a high perceived quality, leading consumers to believe they are a good brand that will benefit their skin.

4. In Indonesia, there are numerous South Korean skincare and cosmetics users who are still enrolled as students or college students. South Korean beauty brands release a variety of products ranging in price from affordable to extremely expensive. Thus, including the price in the review video will be deemed beneficial. Price was also a primary consideration.

5. The South Korean beauty industry can promote itself through drama and television programs, as they serve as a gateway to South Korean popular culture. The greater the level of cosmopolitanism, the higher the perceived value, which results in a more favourable purchase decision. The data also showed that some respondents purchase South Korean beauty products to follow the lifestyle of South Korean celebrities. 
Volume 3 Issue 9 (September 2021) PP. 102-122

DOI 10.35631/AIJBES.39008

6. Enhance the South Korean beauty product presence through a variety of mass media outlets. The data analysis showed that the mass exposure from South Korean beauty brands could increase materialism. However, magazines are not recommended for promoting South Korean beauty products in Indonesia, as the data showed that the majority of the population does not enjoy reading magazines.

\section{Conclusions}

This research focuses exclusively on female respondents, as data indicates that the female segment has become the primary driver of the South Korean beauty industry primarily target female consumers. Most of the respondents are average skincare and cosmetics users, not a person who is highly interested and knowledgeable about beauty products. Apparently, during the respondent search, it was discovered that there is a community for beauty product lovers throughout Indonesia as well as a South Korean celebrities fan community.

The researcher joined several online big groups. Due to the community's size, survey requests often go unnoticed and are intercepted by another chat. Thus, in future research, the researcher could periodically send out survey requests and seek out additional communities on other social media platforms, particularly those comprised of beauty experts, in order to elicit a more nuanced opinion on how to strengthen South Korean beauty brands' market position in Indonesia. Additionally, the researcher discovered that some men completed the questionnaire, and several people expressed disappointment that the questionnaire was restricted to women only, despite the fact that they use beauty products. As a result, it is possible that South Korean cultures' acculturation has an effect on their purchasing decisions regarding South Korean beauty products. As a result, it is recommended that future research include not only female but also male respondents.

Additionally, this research sought to identify significant factors in acculturation to global consumer culture that may influence customers' purchase decisions regarding South Korean skincare and cosmetic products. All of the variables assessed are a significant determinant of customers' purchases of South Korean skincare and cosmetic products. As a result, future research should focus on identifying other additional factors associated with acculturation to global consumer culture that may have a significant impact on customers' purchase decisions regarding South Korean beauty products.

\section{References}

Ajzen, I. (1991). The theory of planned behavior. Organizational Behavior and Human Decision Processes. https://doi.org/10.1016/0749-5978(91)90020-T

Alden, D. L., Kelley, J. B., Riefler, P., Lee, J. A., \& Soutar, G. N. (2013). The effect of global company animosity on global brand attitudes in emerging and developed markets: Does perceived value matter? Journal of International Marketing, 21(2), 17-38. https://doi.org/10.1509/jim.12.0086

Alden, D. L., Steenkamp, J. B. E. M., \& Batra, R. (1999). Brand positioning through advertising in Asia, North America, and Europe: The role of global consumer culture. Journal of Marketing, 63(1), 75-87. https://doi.org/10.2307/1252002

Alden, D. L., Steenkamp, J. B. E. M., \& Batra, R. (2006). Consumer attitudes toward marketplace globalization: Structure, antecedents and consequences. International 
Volume 3 Issue 9 (September 2021) PP. 102-122 DOI 10.35631/AIJBES.39008 Journal of Research in Marketing, 23(3), 227-239. https://doi.org/10.1016/j.ijresmar.2006.01.010

Burhanuddin, H. C. (2016). A COMPARISON ANALYSIS OF PURCHASE DECISION OF WOMEN COSMETIC PRODUCTS IN MANADO (CASE STUDY KOREAN COSMETIC AND INDONESIAN COSMETIC BRAND). JURNAL BERKALA ILMIAH EFISIENSI.

Chin, J. L. (2011). Women and Leadership: Transforming Visions and Current Contexts. Forum on Public Policy: A Journal of the Oxford Round Table, (2), 1-12.

Cleveland, M., \& Laroche, M. (2007). Acculturaton to the global consumer culture: Scale development and research paradigm. Journal of Business Research, 60(3), 249-259. https://doi.org/10.1016/j.jbusres.2006.11.006

Cleveland, M., Laroche, M., \& Takahashi, I. (2015). The Intersection of Global Consumer Culture and National Identity and the Effect on Japanese Consumer Behavior. Journal of International Consumer Marketing, 27(5), 364-387. https://doi.org/10.1080/08961530.2015.1014281

Dodds, W. B., Monroe, K. B., \& Grewal, D. (1991). Effects of Price, Brand, and Store Information on Buyers' Product Evaluations. Journal of Marketing Research. https://doi.org/10.2307/3172866

Ermaningtiastuti, C. (2020). Penjualan Offline Sempat Terhenti, Amorepacifice Alami Penurunan Profit. Marketeers. https://www.marketeers.com/penjualan-offline-sempatterhenti-amorepacifice-alami-penurunan-profit/

Fleetwood, D. (2020). Non-Probability Sampling: Definition, types, Examples, and advantages | QuestionPro. In Https://Www.Questionpro.Com/Blog/Non-Probability-Sampling/.

Garson, G. D. (2016). Partial Least Squares: Regression \& Structural Equation Models.

Gautama, C. A. K. (2015). Pengaruh Country Of Origin Terhadap Purchase Decision (Survei Pada Konsumen Etude House Toserba YOGYA Riau Junction). 1-12.

Henseler, J., Ringle, C. M., \& Sinkovics, R. R. (2009). The use of partial least squares path modeling in international marketing. Advances in International Marketing, 20(2009), 277-319. https://doi.org/10.1108/S1474-7979(2009)0000020014

Howard, C. (2019). Understanding Probability vs. Non-Probability Sampling: Definitive Guide. https://www.cvent.com/en/blog/hospitality/understanding-probability-vs-nonprobability-sampling

Hussain, S., Fangwei, Z., Siddiqi, A. F., Ali, Z., \& Shabbir, M. S. (2018). Structural Equation Model for evaluating factors affecting quality of social infrastructure projects. Sustainability (Switzerland), 10(5), 1-25. https://doi.org/10.3390/su10051415

Keller, K. L. (2013). Conceptualizing, Measuring, and Managing Customer-Based Brand Equity. 57(1), 1-22.

Kelley, J. (2010). Global Consumer Culture: Consumers' Global Brand Attitudes in Brazil and Germany. Global Branding Conference, 1-8. http://home.ku.edu.tr/globalbrand/public_html/files/Kelley.pdf

Kim, E. M., \& Ryoo, J. (2007). South Korean Culture Goes Global: K-Pop and the Korean Wave. Korean Social Science Journal, 34(1), 117-152. http://kossrec.org/board/imgfile/KSSJ Vol.34.no.1(Eun Mee Kim\&Jiwon Ryoo)).pdf

Kim, K. J., \& Han, H. S. (2018). Consumer Acculturation of Chinese Students' Beauty Ideals and Consumption Behavior in a Multicultural Environment. Asian Journal of Beauty and Cosmetology. https://doi.org/10.20402/ajbc.2018.0215

Kotler, P., \& Keller, K. L. (2009). Marketing management (13th ed.). In Prentice Hall. 
Volume 3 Issue 9 (September 2021) PP. 102-122 DOI 10.35631/AIJBES.39008

Lamb, C. W., Hair Jr, J. F., \& Mcdaniel, C. (2011). Marketing. In Climate Change 2013 - The Physical Science Basis

(Vol. http://ebooks.cambridge.org/ref/id/CBO9781107415324A009

Lee, S. J. (2011). The Korean Wave: The Seoul of Asia. The Elon Journal of Undergraduate Research in Communications, 2(1), 85-93.

Malhotra, N. K. (2012). Basic Marketing Research. In Implicit Measures of Attitudes.

Mariani, E. (2008). Delicious Boys Leas Hallyu in Indonesia. Korean Wave, Ed. The Korea Herald, Paju: Jimoondang.

Morwitz, V. (2014). Consumers' purchase intentions and their behavior. Foundations and Trends in Marketing, 7(3), 181-230. https://doi.org/10.1561/1700000036

Newman, E. (2016). Importance of Understanding Customer Behaviour.

Putri, I. P., Liany, F. D. P., \& Nuraeni, R. (2019). K-Drama dan Penyebaran Korean Wave di Indonesia. ProTVF. https://doi.org/10.24198/ptvf.v3i1.20940

Qazzafi, S. (2019). Consumer Buying Decision Process Toward Products. 18(1), 1-12.

Rahmiati, \& Lita. (2012). THE IMPACT OF KOREAN WAVE TO THE ACCEPTANCE OF KOREAN CULTURE AND PRODUCT AMONG INDONESIAN. KDI School of Public Policy and Management.

Ravina, M. (2009). Introduction: Conceptualizing the Korean Wave. Southeast Review of Asian Studies.

Regoli, N. (2019). 18 Advantages and Disadvantages of Purposive Sampling.

Richins, M. L., \& Dawson, S. (1992). A Consumer Values Orientation for Materialism and Its Measurement: Scale Development and Validation. Journal of Consumer Research, 19(3), 303. https://doi.org/10.1086/209304

Riefler, P. (2012). Why consumers do (not) like global brands: The role of globalization attitude, GCO and global brand origin. International Journal of Research in Marketing, 29(1), 25-34. https://doi.org/10.1016/j.ijresmar.2011.11.001

Rohmitriasih, M. (2018). Sesibuk Apapun Aktivitasmu, Penting Tampil Cantik di Depan Suami. https://www.fimela.com/lifestyle-relationship/read/3737732/sesibuk-apapunaktivitasmu-penting-tampil-cantik-di-depan-suami

Schiffman, L. G., \& Kanuk, L. L. (2010). Consumer Behavior 10th Edition. Pearson Education.

Steenkamp, J. B. E. M., Batra, R., \& Alden, D. L. (2002). How Perceived Brand Globalness Creates Brand Value. 3.

Tan, D. S., Thanasegaran, G., Manickiam, N., Sidek, S., Ismail, K., \& Jantan, A. H. (2020). Factors influencing the purchase intention of Korean beauty products among Malaysian females. International Journal of Advanced Science and Technology.

Tjoe, F. Z., \& Kim, K. T. (2016). The effect of Korean Wave on consumer's purchase intention of Korean cosmetic products in Indonesia. Journal of Distribution Science. https://doi.org/10.15722/jds.14.9.201609.65

Wong, K. K. K.-K. (2013). 28/05 - Partial Least Squares Structural Equation Modeling (PLSSEM) Techniques Using SmartPLS. Marketing Bulletin.

Yeomans, J. (2018). Digital Differences. https://isaacintelligence.com/2018/05/04/digitaldifferences/ 